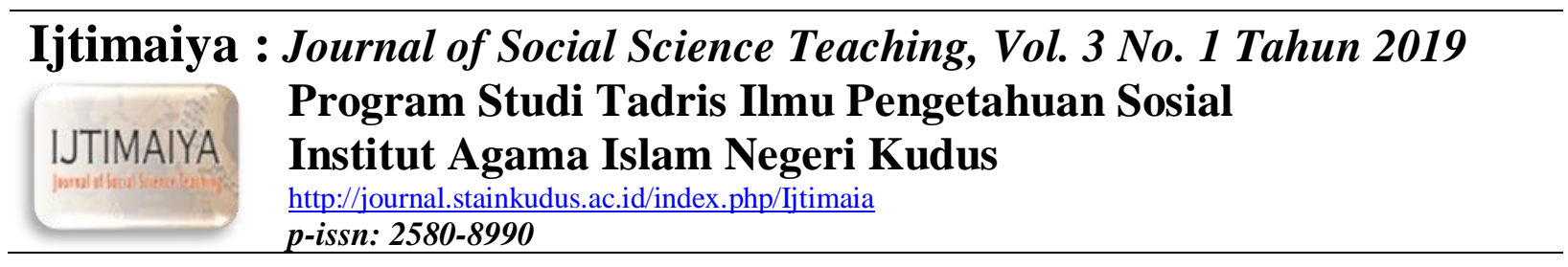

\title{
Identifikasi Perjanjian Kerja Karyawan Kontrak Menurut Undang-undang Nomor 13 Tahun 2003 tentang Ketenagakerjaan di PT. Bima Budidaya Mutiara (BBM) Desa Piong Kecamatan Sanggar Kabupaten Bima
}

\author{
Saddam $^{1}$ Ihsan $^{2}$ \\ a'Dosen PPKn FKIP Universitas Muhammadiyah Mataram, E-mail: saddamalbimiawi1 @ gmail.com \\ ; b Dosen PPKn FKIP Universitas Muhammadiyah Sorong, E-mail: ahmadmihsan0@gmail.com
}

\begin{tabular}{|c|c|}
\hline $\begin{array}{l}\text { Informasi } \\
\text { artikel }\end{array}$ & ABSTRACT \\
\hline $\begin{array}{l}\text { Sejarah artikel: } \\
\text { April } 2019 \\
\text { Mei } 2019 \\
\text { Juni } 2019 \\
\text { Keyword: } \\
\text { Identification } \\
\text { Agreement } \\
\text { Contract } \\
\text { Employment }\end{array}$ & $\begin{array}{l}\text { Lately, the arising problems in an internal company, from pattern making to culminate in } \\
\text { unrest will contract employees in the company's status as a reasonably long time. } \\
\text { Empowerment of employees contract in effect executed in full, but the employees who } \\
\text { belong to particular time work agreements are not fully hired thoroughly. Up to now, there } \\
\text { are indications the granting of jobs generally passes regardless of the official rules of the } \\
\text { applicable employment contract agreement. The method used was qualitative. Data } \\
\text { collection method using observation, documentation, interviews, and triangulation. Data } \\
\text { analysis was conducted in three stages namely data reduction, the presentation of the data, } \\
\text { and draw conclusions. The results showed that certain time work agreements first and } \\
\text { further led to the emergence of the rights and obligations of the parties. There are a number } \\
\text { of principles in the implementation of the employment contract agreement is not yet based } \\
\text { on the procedure of employment rules. The incidence of unrest because of a few things: a } \\
\text { surfeit of employees will be a contract worker status for too long, the company less heed to } \\
\text { the things that can be counted as wages, and the pattern of the Division of work within the } \\
\text { time period for contract employees in the realm of shifts. The company's efforts in coping } \\
\text { with disquiet the contract employee will do some of the following, namely; the efforts of } \\
\text { some employees into contract adoption workers, pay attention to things that can be counted } \\
\text { as wages, and equitable patterns of Division of the period of time in work for the } \\
\text { employee's contract in the realm of shifts. }\end{array}$ \\
\hline
\end{tabular}

\section{ABSTRAK}

\section{Keyword:}

Identifikasi

Perjanjian

Kontrak

Ketenagakerjaan
Akhir-akhir ini timbul permasalahan dalam internal perusahaan, dari pola pengambilan kebijakan hingga berujung pada keresahan karyawan kontrak akan statusnya sebagai di perusahaan yang dirasa lama. Pemberdayaan karyawan kontrak pada asasnya dijalankan secara penuh, akan tetapi karyawan yang tergolong dalam perjanjian kerja waktu tertentu tersebut tidak sepenuhnya diperkerjakan secara menyuluruh. Hingga kini ada indikasi pemberian pekerjaan secara bergilir tanpa memperhatikan aturan resmi tentang perjanjian kontrak kerja yang berlaku. Metode yang digunakan adalah kualitatif. Metode pengumpulan data menggunakan observasi, dokumentasi, wawancara, dan triangulasi. Hasil penelitian menunjukkan bahwa adanya kesepakatan kerja waktu tertentu pertama dan selanjutnya menyebabkan timbulnya hak dan kewajiban para pihak. Ada beberapa prinsip dalam pelaksanaan perjanjian kontrak kerja yang belum berdasarkan prosedur aturan ketenagakerjaan. Timbulnya keresahan karena beberapa hal yakni: kejenuhan karyawan akan status sebagai pekerja kontrak yang terlalu lama, perusahaan kurang memperhatikan hal-hal yang dapat diperhitungkan sebagai upah, dan pola pembagian jangka waktu dalam berkerja bagi karyawan kontrak pada ranah sistem bergilir. Upaya perusahaan dalam mengatasi keresahan karyawan kontrak akan dilakukan beberapa hal berikut, yakni; upaya pengangkatan beberapa karyawan kontrak menjadi pekerja tetap, memperhatikan hal-hal yang dapat diperhitungkan sebagai upah, dan pemerataan pola pembagian jangka waktu dalam berkerja bagi karyawan kontrak pada ranah sistem bergilir. 


\section{Pendahuluan}

Pembangunan nasional dalam rangka pem-berdayaan manusia yang mandiri serta berdayaguna harus memperhatikan aspek kesejahteraan, pemerataan disegala bidang, khususnya mengenai kesempatan kerja tanpa diskriminasi atau pemberlakuan yang sama dalam memperoleh pekerjaan. Eksistensi pekerja sebagai pelaku dan tujuan pembangunan sangat signifikan, karena itu kualitas perlindungan hukum pekerja serta keluarganya harus mendapatkan perhatian dengan seksama. Perlindungan yang dimaksud untuk menjamin hak dasar pekerja, kesamaan kesempatan, non diskriminatif dengan tetap memperhatikan perkembangan kemajuan dunia usaha.

Tujuan pembangunan ketenagakerjaan sebagaimana yang tertera dalam pasal 4 [1] yakni memberdayakan dan mendayagunakan tenaga kerja secara optimal dan manusiawi, mewujud-kan pemerataan kesempatan kerja dan penyedia-an tenaga kerja yang sesuai dengan kebutuhan pembangunan nasional dan daerah, memberikan perlindungan kepada tenaga kerja dalam mewujudkan kesejahteraan, dan meningkatkan kesejahteraan tenaga kerja dan keluarganya.

Konstruksi hukum perusahaan dengan karyawan terlihat pada perumusan perjanjian kerja, dengan pola perjanjian kerja waktu tertentu. Perjanjian kerja diciptakan sebagai dasar bagi pekerja yang dikualifikasikan sebagai tenaga penunjang (kontrak), di mana konstruksi ini dibuat guna membantu keberadaan pekerja dan perusahaan dalam menjalin hubungan kerja, kegiatan penunjang ini tidak langsung bersentuhan dengan proses produksi serta tidak menghambat proses produksi [2]. Hal ini sesuai dengan pernyataan [3] bahwa perjanjian kerja mempunyai manfaat yang besar bagi para pihak yang membuat perjanjian. Penyerahan sebagian pekerjaan dari perusahaan pemberi kerja kepada karyawan dibuat perjanjian secara tertulis atau lisan, hal demikian sesuai dengan penafsiran dalam Pasal 51 ayat 1 [1] bahwa dalam adanya hubungan kerja antara pekerja dan perusahaan diharuskan membuat perjanjian kerja, dan untuk perjanjian yang tertulis dipersyaratkan untuk dilaksanakan sesuai dengan peraturan perundang-undangan. Tujuannya adalah untuk mengatur hubungan kerja, sebagaimana yang dinyatakan [4] kontrak kerja bertujuan untuk mengatur hubungan kerja antara karyawan dan perusahaan yang memperkerjakanya.

Berdasarkan hasil penelitian tentang kesejahteraan buruh/karyawan di perusahaanperusahaan Indonesia, menemukan bahwa sulitnya bagi buruh untuk memperjuangkan sendiri kesejahteraan, mengakibatkan terjadinya ketidakpuasan yang pada akhirnya akan menimbulkan gejolak sosial dan ketidakstabilan perekonomian. Jika tidak ada perwujudan nyata dari pihak-pihak yang berwenang mengenai permasalahan ini, dapat mengakibatkan terjadi-nya stagnasi bahkan kemunduran untuk jangka panjang tidak hanya dari sisi karyawan, juga terhadap perusahaan dan Negara secara keseluruhan. Buruh/karyawan membutuhkan perhatian atas nasib mereka sebagai sumber daya dan aset perusahaan [5].

PT. Bima Budidaya Mutiara (BBM) yang berada di wilayah Desa Piong Kecamatan Sanggar Kabupaten Bima Provinsi Nusa Tenggara Barat (NTB) merupakan salah satu perusahaan yang mengakomodasi tenaga kontrak untuk sejumlah pekerjaan. Akhir-akhir inipun timbulnya permasalahan dalam internal perusahaan dengan para karyawan kontrak. Menurut pengakuan beberapa pekerja kontrak berinisial "R", dan "B" warga Desa Piong bahwa pola pengambilan kebijakan dalam perusahaan menimbulkan keresahan pada karyawan lebih khususnya karyawan kontrak, status kontrak para pekerja berlangsung lama yang merupakan efek dari kurang diperhatikanya perjanjian kontrak kerja waktu tertentu.

Berdasarkan hasil pengamatan awal, PT. BBM Desa Piong mengakomodasi karyawan kontrak dari tahun 2005 melalui perekrutan secara langsung oleh perusahaan, dalam pem- 
berdayaan karyawan kontrak pada asasnya perusahaan menjalankan secara penuh sesuai isi perjanjian kontrak kerjanya, akan tetapi karyawan yang tergolong dalam perjanjian kerja waktu tertentu tersebut tidak sepenuhnya diperkerjakan secara menyuluruh. Timbul keresahan karyawan kontrak dengan adanya kebijakan perusahaan dalam mengetengahi adanya perjanjian kontrak kerja dengan jalan memberikan harapan kepada para karyawan dengan iming-iming pemberian pekerjaan secara bergilir tanpa memperhatikan pola pemberdayaan karyawan kontrak. Hal inipun tidak secara penuh terjadi dalam siklus pekerjaan akan tetapi kadangkala tenaga kontrak diperkerjakan secara menyuluh yang tergolong dalam perjanjian kerja yang sama, bahkan kerap kali perusahaan membutuhkan tenaga tambahan dengan mengait pekerja/karyawan harian lepas. Hal demikian terus terjadi dalam siklus tahunan sehingga sudah banyak menuai kecemburuan sosial antar karyawan kontrak yang satu dengan yang lainya, perselisihan antara karyawan kontrak dengan pihak perusahaan, bahkan menumbuhkan perselisihan dan keresahan karyawan kontrak. Hal demikian sudah terjadi kurang lebih 8 (delapan) tahun masa kerja karyawan kontrak, dan ada kemungkinan sudah melangkahi aturan ketenagakerjaan yang berlaku, lebih-lebih Undang-undang No. 13 Tahun 2003.

Berdasarkan uraian di atas, maka penelitian ini bertujuan; 1). untuk mengetahui bagaimana hubungan hukum perjanjian kontrak kerja antara karyawan dengan manager perusahaan berdasarkan Undangundang No. 13 Tahun 2003. 2). untuk mengetahui faktor-faktor apa saja penyebab timbulnya keresahan karyawan terhadap perjanjian kontrak kerja di PT. BBM Desa Piong. Dan 3). untuk mengetahui bagaimana upaya manager perusahaan untuk mengatasi berbagai keresahan karyawan terhadap perjanjian kontrak kerja di PT. BBM Desa Piong.

\section{Metode}

Pemecahan masalah dalam penelitian ini menggunakan metode penelitian kualitatif. Metode penelitian kualitatif digunakan untuk meneliti pada kondisi objek yang alamiah, di mana peneliti adalah sebagai instrumen kunci, [6]. Lebih lanjut [7] bahwa penelitian kualitatif adalah penelitian yang bermaksud untuk memahami fenomena tentang apa yang dialami, prosesnya dari berbagai langkah selalu dilibatkan peneliti, guna memahami fenomena secara holistik dan dalam bentuk kata-kata dan bahasa, pada suatu konteks khusus yang alamiah.

Metode ini digunakan untuk menguraikan hubungan hukum perjanjian kerja karyawan kontrak dengan PT. BBM Desa Piong. Dimaksudkan semata-mata untuk mengidentifikasi tentang perjanjian kerja karyawan kontrak berdasarkan Undang-undang No. 13 Tahun 2003.

Subjek Penelitian

Penentuan subjek penelitian dalam penelitian kualitatif, mengacu pada pendapat [6] bahwa dalam penelitian kualitatif tidak menggunakan populasi, karena penelitian kualitatif berangkat dari kasus tertentu yang ada pada situasi sosial tertentu dan hasil kajianya tidak akan diberlakukan ke populasi.

Teknik sampling yang digunakan dalam penelitian ini yaitu purposive sampling. Maka yang menjadi sampel dalam penelitian ini adalah manajer, staf-staf, dan karyawan kontrak PT. BBM Desa Piong. Hal ini guna mendapatkan data tentang perjanjian kerja karyawan kontrak baik dari pihak pekerja dan juga pemberi kerja.

\section{Lokasi Penelitian}

1. Letak Geografi PT. Bima Budidaya Mutiara

Penelitian ini dilakukan di PT. BBM Desa Piong Kecamatan Sanggar Kabupaten Bima, merupakan perusahaan yang bergerak dibidang pembudidayaan mutiara. Pada umumnya wilayah kecamatan Sanggar termasuk Desa Piong dan beriklim tropis dengan curah hujan relatif tinggi, musim hujan yang terjadi antara bulan oktober sampai dengan april dengan curah hujan rata-rata $271,5 \mathrm{~mm}$ pertahun. 
PT. BBM dominan menggunakan wilayah laut sedangkan wilayah daratan hanya sebagai pemukiman untuk perkantoran dan tempat singgah beberapa karyawan dan petinggi perusahaan. Luas wilayah perusahaan \pm 1.664 Ha (1,5 Ha wilayah darat sebagai pemukiman dan kantor perusahaan sedangkan $\pm 1.663,5$ Ha wilayah laut sebagai penopang pembudidayaan mutiara). Batas wilayah PT. BBM yaitu sebelah barat jalan raya lintas Tambora, sebelah utara ladang masyarakat Desa Piong, sebelah timur teluk Saleh, sebalah selatan mata mata air tampiro.

Tabel 1.

Jumlah karyawan Menurut Jenis Kelamin

\begin{tabular}{|c|c|c|c|}
\hline Kelompok Kerja & \multicolumn{3}{|c|}{ Laki-laki } \\
\hline Perempuan & Por & ase & \\
\hline Karyawan Tetap & 55 & 65 & $33 \%$ \\
\hline Karyawan Kontrak & 44 & 56 & $27 \%$ \\
\hline Harian Lepas & 56 & 90 & $40 \%$ \\
\hline Jumlah & 211 & $100 \%$ & \\
\hline
\end{tabular}
kelamin.

2. Struktur Organisasi Perusahaan

Berikut Struktur Organisasi PT. BBM Desa Piong:

Bagan 1. Struktur Organisasi Perusahaan

Sumber: PT. BBM Desa Piong.

3. Keadaan Demografi Karyawan

Jumlah karyawan PT. BBM Desa Piong dari tahun ketahun bulan ke bulan mengalami perubahan baik yang disebabkan karena kematian, pendatang luar maupun perpindahan dan juga pada pembatasan pekerja pada waktu tertentu oleh pihak perusahaan yang sasaranya adalah karyawan kontrak, sehingga secara grafik kebutuhan perusahaan akan karyawan penunjang seperti karyawan kontrak dan harian lepas sangat bergantung pada kebijakan perusaha-an disesuaikan dengan iklim kerja. Secara umum terdapat tiga golongan pekerja di PT. BBM yakni karyawan yang diikat dalam Perjanjian Kerja Waktu Tidak Tertentu (PKWTT) atau karyawan tetap, karyawan yang diikat dalam PKWT atau karyawan kontrak dan yang ketiga adalah golongan karyawan harian lepas yang direkrut tanpa ada perjanjian kerja.

Tabel 2

Jumlah Karyawan Menurut Kelompok Kerja

Kelompok Kerja Frekuensi (Jiwa) Porsentase

PKWTT/ Karyawan Tetap $120 \quad 33 \%$

PKWT/ Karyawan Kontrak $100 \quad 27 \%$

Harian Lepas $\quad 146 \quad 40 \%$

Sumber:Data karyawan menurut kelompok kerja.

Hal di atas menunjukkan bahwa pada mulanya pekerjaan di perusahaan ini memang mengarah pada etos kerja perempauan karena lebih ke cara perawatan dalam pembudidayaan mutiara, namun tidak bisa dipungkiri sebagai penunjang dan tenaga yang tangguh kaum laki-laki tetap dibutuhkan dengan sangat dalam pekerjaan tertentu.

Metode Pengumpulan Data

1) Metode Observasi

Observasi adalah tehnik pengumpulan data dengan cara pengamatan didasarkan atas pengalaman secara langsung (melihat atau mengamati sendiri). Nawawi dan Martini dalam [8] observasi adalah pengamatan dan pencatatan secara sistematik terhadap unsurunsur yang tampak dalam suatu gejala atau gejala-gejala dalam objek penelitian.

Peneliti melakukan observasi langsung terhadap keberadaan karyawan kontrak dan perjanjian kontrak kerjanya di PT. BBM Desa Piong, dengan mengamati secara langsung peristiwa/ gejala yang timbul pada karyawan kontrak dan pihak perusahaan. Metode observasi digunakan untuk memperoleh data secara langsung tentang perjanjian kerja karyawan kontrak.

2) Metode Wawancara

Wawancara adalah percakapan dengan maksud tertentu. Percakapan itu dilakukan oleh dua pihak, yaitu pewawancara (interviewer) yang mengajukan pertayaan dan terwawancara (interviewee) yang memberikan jawaban atas pertayaan itu[7]. Lebih lanjut, dalam [8] dijelaskan bahwa wawancara adalah metode pengambilan data dengan cara 
menanyakan sesuatu kepada seseorang yang menjadi informan atau responden. Caranya adalah dengan bercakap-cakap secara tatap muka.

Peneliti melakukan wawancara terhadap karyawan kontrak dan juga pada pihak PT. BBM Desa Piong untuk memperoleh data tentang lama/tidaknya karyawan kontrak bekerja dalam urun waktu perjanjian kerjanya (eksistensi perjanjian kontrak kerja dalam pemberdayaan karyawan kontrak) serta hal apa yang dilakukan manajer perusahaan untuk mengatasi berbagai keresahan karyawan terhadap perjanjian kontrak kerja tersebut. Arahnya menggali kesesuaian perlakuan perusahaan terhadap karyawan kontrak dengan Undang-Undang Nomer 13 Tahun 2003.

3) Metode Dokumentasi

Metode dokumentasi adalah teknik pengumpulan data dan informasi melalui pencarian dan penemuan bukti-bukti. Metode dokumenter ini merupakan metode pengumpulan data yang berasal dari sumber nonmanusia [8]. Metode dokumentasi digunakan untuk mengumpulakan data-data, arsip-arsip, dan catatan-catatan tertulis tentang perjanjian kerja karyawan kontrak serta hak dan kewajiban para pihak (Karyawan kontrak dan pihak PT. BBM Desa Piong berdasarkan Undang-Undang Nomer 13 tahun 2003.

4) Metode Triangulasi

Triangulasi ada dua macam yakni triangulasi teknik dan triangulasi sumber: Trangulasi teknik, berarti peneliti menggunakan teknik pengumpulan data yang berbeda-beda untuk mendapatkan data dari sumber yang sama. Peneliti menggunakan observasi partisipatif, wawancara mendalam, dan dokumentasi untuk sumber data yang sama secara serempak. Triangulasi sumber berarti, untuk mendapatkan data dari sumber data yang berbeda-beda dengan teknik yang sama[6].

Metode triangulasi digunakan untuk memper-oleh data tentang perjanjian kerja karyawan kontrak di PT. BBM Desa Piong. Data dari karyawan kontrak, supervisor dan juga pada pihak PT. BBM Desa Piong dicocokan satu sama lain guna membuktikan keontentikan data yang diperoleh.

Jenis dan Sumber Data

1) Jenis Data

Jenis data itu dapat digolongkan menjadi dua bagian yaitu: Data kuantitatif yaitu data yang berbentuk angka, atau data kualitatif yang diangkakan (skoring). Data kualitatif adalah data yang berbentuk kalimat, kata atau gambar [6]. Data yang digunakan dalam penelitian ini berupa data kualitatif karena data dalam penelitian ini berbentuk kalimat, kata ataupun gambar dan simbol yang berkaitan dengan penelitian ini.

2) Sumber Data

Menurut Lofland dalam [7] sumber data utama dalam penelitian kualitatif ialah katakata, dan tindakan, selebihnya adalah data tambahan seperti dokumen dan lain-lain. Ada tiga macam sumber data di dalam penelitian ini [9], yakni sumber data primer, data sekunder, dan data tersier.

Sumber data primer dalam penelitian ini diperoleh melalui hasil wawancara berdasarkan pedoman wawancara, data sekunder berupa dokumen-dokumen, catatancatatan yang ada hubunganya dengan penelitian di PT. BBM Desa Piong.

Analisis Data

Analisis data itu dilakukan dalam suatu proses. Proses berarti pelaksanaanya mulai dilakukan sejak pengumpulan data dan dikerjakan secara intensif, yaitu sesudah meninggalkan lapangan. Untuk menganalisa data yang diperoleh dari penelitian ini, digunakan analisis data kualitatif, karena data yang diperoleh dari hasil metode pengumpulan data hanya berupa gambaran masalah dengan kata-kata biasa atau simbol.

Dengan demikian analisis data kualitatif dilakukan melalui tiga tahap[10] yakni; 1). Reduksi data merupakan suatu bentuk analisis yang menanyakan, menggolongkan, mengarahkan mem-buang yang tidak perlu dan mengorganisasi-kan data dengan cara sedemikian rupa sehingga kesimpulan final dapat ditarik. 2). Penyajian data adalah kesimpulan informasi tersusun yang memberi 
kemungkinan adanya penarikan kesim-pulan dan pengambilan tindakan. Dan 3) Menarik kesimpulan, penarikan kesimpulan dilakukan reduksi data dan penyajian data. Penarikan kesimpulan dan pengambilan tindakan.

Pengujian Keabsahan Data

Keabsahan data adalah suatu rangkaian yang dilakukan oleh peneliti dalam rangka untuk membuktikan data yang diperoleh berdasarkan hal yang sebenarnya dan kredibilitas data itu sendiri bertujuan untuk membuktikan apa yang diamati oleh peneliti yang sesuai dengan kenyataan. Untuk menetapkan keabsahan data diperlukan teknik pemeriksaan. Pelaksanaan teknik pemeriksaan didasarkan atas sejumlah kriteria tertentu. Menurut Sanafiah Faisal dalam [6] ada 4 (empat) kriteria yang digunakan, yaitu; 1). Derajat keper-cayaan (credibility), 2) Keteralihan (transfera-bility), 3) Kebergantungan (depend-ability), dan 4) Kepastian (convirmability).

\section{Hasil dan Pembahasan}

Hubungan Hukum yang Disepakati

Pelaksanaan hubungan hukum yang disepakati di PT. BBM Desa Piong dikaji berdasarkan Undang-undang No. 13 Tahun 2003 adalah sebagai berikut:

1) Status dalam Berkerja

Perekrutan karyawan kontrak di perusahaan ini dilakukan secara langsung oleh perusahaan. Hal tersebut sudah terjadi sejak Januari 2005, di mana pada momen ini terjadi kesepakatan kerja partama antara kedua belah pihak. Dengan ini, karyawan berstatus pekerja kontrak dari timbulnya kesepakatan kerja pertama sejak januari 2005 tersebut. Jadi, lama karyawan berstatus kontrak sudah mencapai 8,5 tahun.

Ketentuan dalam hal masa kerja atau jangka waktu dalam berkerja bagi karyawan dengan status pekerja kontrak kemudian diatur dalam Pasal 59 ayat 4 [1] yang berbunyi "Perjanjian kerja waktu tertentu yang didasarkan atas jangka waktu tertentu dapat diadakan untuk paling lama 2 (dua) tahun dan hanya boleh diperpanjang 1 (satu) kali untuk jangka waktu paling lama 1 (satu) tahun". Selanjutnya PKWT dapat diperbarui sebagaimana yang diatur dalam Pasal 59 ayat 6 [1] yang berbunyi: "Pembaruan perjanjian kerja waktu tertentu hanya dapat diadakan setelah melebihi masa tenggang waktu 30 (tiga puluh) hari berakhirnya perjanjian kerja waktu tertentu yang lama, pembaruan perjanjian kerja waktu tertentu ini hanya boleh dilakukan 1 (satu) kali dan paling lama 2 (dua) tahun". Berdasarkan bunyi pasal tersebut waktu kontrak hanya boleh dan dalam kurun waktu 5 (lima) tahun masa kerja terhitung dari perjanjian kontrak kerja awal, setelah itu perusahaan harus menentukan apakah mengcukupkan masa kontrak atau memperkerjakan karyawan dengan catatan mengangkat karyawan tersebut sebagai karyawan tetap.

Kenyataanya karyawan berkerja dengan status pekerja kontrak di PT. BBM Desa Piong sudah mencapai 8,5 (delapan koma lima) tahun terhitung sejak januari 2005 hingga sekarang, tanpa ada perubahan status yang disandangnya. Menurut pihak manajemen perusahaan status para karyawan sebagai pekerja kontrak yang terlalu lama ini murni terjadi karena pertimbangan pihak perusahaan akan kondisi pendapatan perusahaan yang secara langsung akan berpengaruh jika dilakukan pengangkatan para pekerja kontrak menjadi karyawan tetap. Faktor alam menjadi pengaruh utama pada iklim kerja sehingga dimungkinkan jika dilakukan pengangkatan karya-wan kontrak menjadi pekerja tetap maka akan timbul kelebihan tenaga kerja pada sejumlah pekerjaan, sehingga secara langsung akan me-nimbulkan pemborosan tenaga kerja, mengingat kondisi ada/tidaknya pekerjaan diperusahaan sangat dipengaruhi oleh faktor alam.

Status karyawan sebagai pekerja kontrak di PT. BBM Desa Piong sudah melampaui batas minimum dalam kontrak sebagaimana yang diatur dalam Pasal 59 ayat 4 dan 6[1]. Hal ini menunjukan secara hukum status para karyawan tersebut bukan lagi sebagai pekerja kontrak melainkan berstatus pekerja tetap. 


\section{2) Struktur Upah/Gaji}

Besar upah bagi para pekerja kontrak adalah Rp. 4.300/hari dikalikan jumlah hari kerja. Pasalnya penghitungan gaji hanya pada hari kerja sedangkan yang diluar hari kerja karena berhalangan dan waktu istrahat kerja tidak dikalkulasikan sebagai jumlah hari untuk penghitungan gaji. Setiap pekerja/buruh berhak memperoleh penghasilan yang memenuhi penghidupan yang layak bagi kemanusiaan dengan ini pemerintah menetapkan kebijakan pengupahan yang melindungi pekerja/ buruh, diantara kebijakan pengupahan yang melindungi pekerja/buruh ter-sebut adalah upah berdasarkan upah minimum yang distandarkan pada upah minimum provinsi (UMP), upah kerja lembur, upah tidak masuk kerja karena berhalangan, upah tidak masuk kerja karena melakukan kagiatan lain diluar pekerjaanya, upah karena men-jalankan waktu istrahat kerjanya, bentuk dan cara pembayaran upah, denda dan potongan upah, hal-hal yang dapat diperhitungkan dengan upah, struktur dan skala pengupahan yang proporsional, upah untuk pembayaran pesangon, dan upah untuk penghitungan pajak penghasilan.

PT. BBM Desa Piong melaksanakan struktur pengupahan dengan berdasarkan pada skala jumlah hari kerja sedangkan untuk halhal lain yang diluar hari kerja tidak diperhitungkan sebagai hari untuk pengkalkulasian jumlah upah. Mengacu pada Upah Minimum Provinsi NTB 1,1 juta rupiah perbulannya dan dikaitkan dengan cara penghitungan upah diperusahaan, maka upah perharinya Rp. 43.000 dikalikan jumlah hari kerja karyawan perbulannya secara penuh mencapai Rp. 1.118.000 dan sudah mencapai standar upah minimum provinsi Nusa Tenggara Barat, jika kondisi hari kerja karyawan perbulanya 26 hari. Jika berbalik karena karyawan sakit, berhalangan dan harihari libur umum maka jumlah gaji karyawan kurang dari standar upah minimum provinsi.

Tentang hal di atas telah dijelaskan dalam Pasal 88 [1], di mana ada beberapa poin yang menjadi hak para pekerja. Namun dalam hal ini diabaikan oleh perusahaan jika mengacu pada pasal tersebut diantaranya adalah:

a) Upah tidak masuk kerja karena berhalangan

Berdasarkan hasil observasi dan wawancara yang dilakukan peneliti bahwa PT. BBM Desa Piong hanya mengkalkulasikan pengupahan berdasarkan jumlah hari kerja, sedangkan hari-hari lain yang diluar hari kerja baik itu karena berhalangan (sakit atau istri melahirkan) tidak dijadikan sebagai hari untuk penghitungan gaji/upah. Ketentuan mengenai upah yang dibayarkan kepada karyawan sakit sehingga tidak dapat melakukan pekerjaan diatur dalam Pasal 93 ayat 3[1] di mana untuk 4 (empat) bulan pertama dibayar $100 \%$ dari upah, 4 (empat) bulan kedua dibayar $75 \%$ dari upah, 4 (empat) bulan ketiga dibayar $50 \%$ dari upah, dan untuk 4 (empat) bulan selanjutnya dibayar $25 \%$ dari upah sebelum pemutusan hubungan kerja dilakukan oleh pihak pemberi kerja.

b) Upah tidak masuk kerja karena melakukan kegiatan lain di luar pekerjaannya

Dari hasil observasi dan wawancara yang dilakukan peneliti bahwa ketika para pekerja ada acara keluarga, menikah, menikahkan, menjalankan kewajiban Negara atau menjalankan ibadah, hari-hari tersebut tidak dikalkulasikan sebagai hari untuk penghitugan gaji. Padahal upah dibayarkan pada karyawan yang tidak masuk kerja karena karyawan/pekerja menikah, menikahkan, mengkhitankan, membaptiskan anak, istri melahirkan atau keguguran kandungan, anggota keluarga meninggal dunia jelas-jelas diatur dalam Pasal 93 ayat 4 [1]. Demikian juga jika karyawan melakukan pekerjaan karena sedang menjalankan kewajiban terhadap Negara dan Agama.

Berdasarkan hal di atas menurut peneliti upah tidak masuk kerja karena melakukan kegiatan lain diluar pekerjaannya secara normatif harus dibayarkan perusahaan berdasar pada ketentuan hari yang distandarkan perusahaan. Kabiasaan sudah tidak berpengaruh ketika hal tersebut diatur 
dengan jelas dalam Undang-undang, mengingat hal tersebut hanya kebiasaan.

c) Upah karena menjalankan hak waktu istrahat kerjanya.

Ketika karyawan kontrak izin istrahat berdasarkan hak waktu istrahat yang diberikan, hak waktu istrahat ini tidak dikalkulasikan sebagai jumlah hari untuk penghitungan gaji/upah. Dalam Pasal 93 ayat 2 [1] dikatakan pengusaha wajib membayar upah apabila karyawan melaksanakan hak waktu istrahatnya. Hal yang sama diungkapkan pihak manajemen perusahaan alasan utama mengenai hal ini sudah terjadi menurut kebiasaan sejak awal berdirinya perusahaan. Pasalnya dalam catatan gaji karyawan terkategori dalam struktur pengupahan pekerja harian lepas, hal gaji pastinya bergantung pada hari dimana karyawan tersebut masuk kerja.

Dengan demikian menurut peneliti upah karena menjalankan hak waktu istrahat kerjanya harusnya diperhatikan oleh perusahaan. Waktu istrahat merupakan hak para karyawan setelah berkerja berturut-turut menurut ketentuan, sehingga menimbulkan hak waktu istrahat. Sudah seharusnya perusahaan mengkalkulasikan hari dalam hak waktu istrahat tersebut sebagai hari kerja.

3) Hak dan Kewajiban Para Pihak

Berdasarkan hasil penelitian yang dilakukan peneliti di PT. BBM Desa Piong serta kaitanya dengan hak dan kewajiban para pihak yang timbul dari adanya KKWT tersebut adalah:

a) Mengadakan Kesepakatan Kerja

Pada proses pengadaan PKWT perusahaan merumuskan secara sepihak perjanjian kerja tersebut, kemudian diberikan untuk dibaca dan dipahami oleh para pekerja sebelum ditandatangani. Padahal jelas-jalas dikatakan dalam Pasal 54 ayat 3 [1] mengharuskan perjanjian kerja yang mempunyai kekuatan hukum yang sama dipegang oleh masing-masing pihak (pekerja/ buruh dan pengusaha) dan dibuat secara bersama.

Kenyataan lapangan menunjukkan bahwa dalam perumusan perjanjian kerja karyawan tidak dilibatkan secara langsung oleh perusahaan, melainkan karyawan hanya diberikan kesempatan untuk membaca dan memahami isi perjanjian kerja yang sudah jadi, lalu disertakan untuk ditanda-tangan setelah itu berkas yang ditandatangan diserahkan kembali kepihak perusahaan. Hal di atas terus terjadi dalam siklus peristiwa kesepakatan kerja diperusahaan dimana hasil kesepakatan kerja yang memiliki kekuatan hukum ynag sama tersebut diarsipkan oleh perusahaan tanpa diberikakan pada pekerja kontrak. Hal tersebut bukan sepenuhnya kesalahan perusahaan melainkan kurangnya kesadaran para karyawan kontrak akan perlunya mengikuti proses dan penetapan perjanjian kerja serta memegang isi kesepakatan kerja yang memiliki kekuatan hukum yang sama.

b) Merumuskan Peraturan Perusahaan

Proses perumusan peraturan perusaha-an di PT. BBM Desa Piong tidak melibatkan karyawan secara menyeluruh, yang dilibatkan hanya tiga orang perwakilan karyawan/ pekerja. Umumnya karyawan yang telibat dalam perumusan peraturan perusa-haan tidak mengambil andil dalam pembahasan peraturan perusahaan tersebut, melainkan hanya membaca dan memahami setelah dirumuskan oleh pihak perusahaan, setelah itu apabila perwakilan karyawan menyetujui isi peraturan perusahaan maka disertakan untuk ditandatangani. Setelah peraturan perusahaan tersebut terumus dan disahkan oleh pejabat yang berwajib perusahaan mengarsipkan peraturan perusa-haan tersebut tanpa diberikan pada karyawan. Secara umum dalam setiap siklus perumusan dan pengesahan ulang peraturan perusahaan perwakilan karyawan sepakat dengan dengan isi peraturan perusahaan tersebut, sehingga secara normatif peraturan perusahaan ini memang terlihat hasil kerja dan rumusan antara karyawan dan pihak perusahaan.

4) Sistem Bergilir dalam Berkerja

Untuk menyeimbangkan pemberdayaan karyawan kontrak, PT. BBM Desa Piong menerapkan sistem bergilir dalam berkerja. Pada 
pola pembagian jangka waktu dalam berkerja bagi karyawan kontrak dengan sistem bergilir ini, karyawan kontrak dibagi dalam dua kelompok kerja, dan diperkerja-kan secara bergilir diperusahaan. Segolongan pekerja kontrak yang dibilang pada pola pemberian kerja secara bergilir untuk karyawan kontrak pada perusahaan ini kadang ada yang bekerja hanya 2 (dua) atau 3 (tiga) bulan setelah itu dipanggil lagi segolongan pekerja kontrak lain kemudian diperkerjakan dalam jangka waktu yang lebih dari waktu yang diberikan untuk sekelompok pekerja kontrak sebelumnya. Hal ini sudah terjadi untuk 2 (dua) tahun akhirakhir ini dan sempat menjadi bumerang berkepa-njangan yang diperbincangkan oleh para pekerja. Melihat pembagian jangka waktu yang berbeda dalam berkerja pada penerapan sistem bergilir sudah terjadi dalam kurun waktu dua tahun akhir-akhir ini, secara langsung pihak perusahaan melanggar asas penerapan dan kesepakatan dalam sistem bergilir yakni bagaimana menyeimbangkan kondisi pekerjaan dengan para karyawan agar tercipta keadilan dalam menberikan pekerjaan pada karyawan kontrak dan kebutuhan

Penerapan sistem ini adalah wujud dari hasil kesepakatan antara pihak perusahaan dengan karyawan, namun dalam penerapannya perusahaan memberikan perlakuan yang berbeda pada jangka waktu pembagian kerja untuk karyawan kontrak. Perlakuan berbeda ini bukan sepenuhnya karena faktor kesengajaan pihak perusahaan melainkan karena iklim kerja sangat dipengaruhi faktor alam.

Hubungan hukum yang timbul dari perjanjian kontrak kerja antara karyawan dengan manajer PT. BBM Desa Piong berdasarkan Undang-undang No. 13 Tahun 2003 tentang Ketenagakerjaan setelah adanya KKWT pertama dan selanjutnya, yang kemudian mengharuskan adanya penyelenggaraan hak dan kewajiban para pihak. Disepakati beberapa hal yakni srtuktur upah, penyelenggaraan hak dan kewajiban para pihak, penerapan sistem bergilir dalam berkerja bagi karyawan kontrak dan mengenai status. Dari segi pelaksanaanya ada beberapa pelanggaran yang dilakukan oleh perusahaan diantaranya adalah status para karyawan sebagai karyawan kontrak melebihi batas minimum kontrak, hal-hal yang dapat diperhitungkan sebagai upah, perumusan perjanjian kerja tidak dilibatkan karyawan secara langsung serta isi KKWT yang memiliki kekuatan hukum yang sama tidak diberikan pada karyawan, peraturan perusahaan yang disahkan oleh pemerintah yang berwajib tidak diberikan pada karyawan dan terakhir pemberian jangka waktu yang berbeda dalam sistem bergilir bagi sebagian karyawan kontrak.

Dari pembahasan diatas dapat disimpulkan ada hubungan secara teoritis dengan teori Flipo bahwa:

Seorang manajer seluruh hierarki perusahaan adalah seorang yang melaksanakan otoritas dan kepemimpinan atas orang lain. Seorang pelaksana adalah seorang yang tidak memiliki otoritas atas orang lain akan tetapi diberi tugas atau kewajiban untuk melaksanakan dibawah pengendalian seorang manajer. Oleh karena itu, manajer tenaga kerja adalah seorang manajer dan sebagai manajer ia harus melaksanakan fungsi pokok manajemen. Namun demikian, perumusan manajemen tenaga kerja harus mengandung dua fungsi, yakni: 1). Fungsi Administratif (Administrative Function); Fungsi ini merupakan serangkaian kegiatan yang harus dijalankan mana-jemen tenaga kerja sejalan dengan peraturan sistem administrasi ketenaga-kerjaan Republik Indonesia. 2). Fungsi Operasional (Operasional Function); Fungsi ini merupakan serangkaian tindakan yang harus dilakukan manajemen tenaga kerja sejalan dengan wewenang dan tanggung jawabnya dalam perusahaan besar, fungsi ini cenderung didelegasikan kepada manajemen karena lebih banyak menyangkut kegiatan perusahaan yang sifatnya operasional [11].

Hal di atas juga sejalan dengan teori [11] di mana tingkat efektivitas tenaga kerja sangat dipengaruhi oleh pembinaan, pengaturan, peng-urusan, pendayagunaan, dan 
pengembangan yang dilakukan oleh manajemen tenaga kerja, karena manajemen tenaga kerja memiliki tanggung jawab langsung terhadap pembinaan tenaga kerja yang menjadi bawahanya. Dengan demikian, manajemen tenaga kerja memiliki tanggung jawab besar terhadap efektivitas tenaga kerja. Seorang manajer tenaga kerja memerlukan kelihaian dalam menyelami keinginan tenaga kerja yang menjadi bawahan dan tanggung jawabnya. Pendekatan psikologis perlu dilakukan manajer tenaga kerja agar hasilnya produktif.

Faktor Penyebab Timbulnya Keresahan Karyawan Kontrak

1) Kejenuhan karyawan akan status sebagai karyawan kontrak

Dari hasil penelitian yang peneliti dapatkan bahwa kurun waktu karyawan dikontrak sebelum dan pada taraf penerapan sistem bergilir selalu diawali dengan penandatanganan perjanjian kontrak baru. Hal ini diterapkan dalam 8 (delapan) tahun masa kerja karyawan kontrak diperusahaan, untuk dua tahun akhir-akhir ini diterapkan bersamaan dengan sistem bergilir dalam berkerja bagi karyawan kontrak.

Kejenuhan tersebut secara langsung timbul pada diri para karyawan kontrak setelah mengetahui tentang hukum kontrak dan batas minimum berkerja dengan status sebagai karyawan kontrak. Dimana karyawan dapat diperkerjakan dengan status sebagai karyawan kontrak maksimal 5 (lima) tahun masa kerja, selebihnya jika perusahaan masih membutuhkan tenaga para karyawan maka harus diangkat menjadi karyawan tetap.

2) Kurang diperhatikan hal-hal yang dapat diperhitungkan sebagai upah

Sebagaimana yang disebutkan pada bagian pertama, hal-hal dalam ketentuan pembayaran upah tersebut yakni:

a) upah tidak masuk kerja karena berhalangan.

b) upah tidak masuk kerja karena melakukan kegiatan lain diluar pekerjaannya.

c) upah karena menjalankan hak waktu istirahat kerjanya.
Selain pada ranah kejenuhan karyawan akan statusnya sebagai pekerja kontrak yang terlalu lama, hal lain juga yang menyebabkan keresahan karyawan kontrak adalah diabaikannya beberapa hal yang menjadi hak karyawan kontrak diantaranya adalah upah tidak masuk kerja karena berhalangan, upah tidak masuk kerja karena melakukan kegiatan lain diluar pekerjaannya, upah karena menjalankan hak waktu istirahat kerjanya. Hal ini secara langsung diabaikan oleh pihak perusahaan dari pertama masa kerja karyawan kontrak hingga karyawan kontrak mengetahui ada hari-hari yang memang harus dikalkulasikan sebagai hari kerja karyawan.

Menurut pihak manajemen perusahaan, alasan utama mengenai upah yang tidak dibayarkan kepada karyawan yang tidak masuk kerja karena berhalangan, upah tidak masuk kerja karena melakukan kegiatan lain diluar pekerjaannya dan upah karena menjalankan hak waktu istirahat kerjanya adalah karena hal ini sudah terjadi menurut kebiasaan sejak awal berdirinya perusahaan. Pasalnya dalam catatan gaji karyawan terkategori dalam struktur pengupahan pekerja harian lepas, lagi pula menurut pihak manajemen perusahaan jamsostek untuk karyawan berjalan dengan baik, hal gaji pastinya bergantung pada hari dimana karyawan tersebut masuk kerja.

Sadar akan ketidakadilan kebijakan perusahaan, para pekerja kontrak mulai menuntut hak dan keadilan dari segala kebijakan perusahaan. Permasalahan ini tidak sampai pada mogok kerja karena yang merasa pembedaan perlakuan hanya sebagian dari karyawan yang menunggu giliran untuk berkerja, karyawan masih merasa butuh akan pekerjaan diperusahaan tersebut, hanya saja sebagian dari karyawan kontrak inilah yang bergerak untuk menyelesaikan permasalahan tersebut walaupun hasilnya akan dirasakan juga oleh semua karyawan kontrak.

3) Hak dan kewajiban masing-masing pihak/para pihak

Perumusan perjanjian kerja sepihak oleh perusahaan, diabaikannya beberapa hal yang 
menjadi hak karyawan kontrak diantaranya adalah isi KKWT yang memiliki kekuatan hukum yang sama tidak diberikan kepada karyawan kontrak, perumusan peraturan perusa-haan hanya disertakan 3 (tiga) orang dari karyawan dan hasil perumusan peraturan perusahaan yang disahkan pemerintah yang berwajib tidak diberikan pada karyawan. Hal ini secara langsung diabaikan dari setiap siklus perumusan perjanjian kerja dan perumusan/pengesahan peraturan perusa-haan. Hingga timbul kesadaran para karyawan kontrak akan pentingnya hal-hal tersebut.

Menurut pihak perusahaan, hal ini terjadi karena kurangnya kesadaran karyawan akan perlunya mengikuti proses dan penetapan perjanjian kerja serta memegang isi perjanjian kerja yang ditetap-kan. Pada intinya karyawan menginginkan prosesnya seperti ini tanpa harus melibatkan mereka, yang mereka inginkan hanya berkerja dan mendapatkan upah. Biasanya yang wajib para karyawan ingin tahu hanya jangka waktu mereka dalam berkerja dan kalkulasi upah yang akan terhitung. Diabaikanya beberapa hal yang menjadi hak dan kewajiban oleh masingmasing pihak dalam hal ini pada proses perumusan dan pengesahan ulang perjan-jian kerja dan peraturan perusahaan dikarenakan kurangnya kesadaran kedua belah pihak akan perlunya merumuskan dan membahas secara seksama isi perjanjian dan peraturan perusahaan tersebut.

Hal ini secara langsung menimbulkan keresahan bagi pihak karyawan ketika timbul permasalahan dalam internal perusahaan, dimana para karyawan kontrak menginginkan peraturan perusahaan untuk acuan dalam berkerja namun pihak perusahaan kurang mengindahkan. Ini menunjukan bentuk ketidak pedulian para pihak akan hal-hal tersebut disaat suasana kerja terjalin harmonis, selebihnya ketika timbul permasalahan dalam internal perusahaan, para pekerja kontrak merasa membutuhkan peraturan perusahaan.

Terdapat empat faktor penyebab timbulnya keresahan karyawan terhadap perjanjian kontrak kerja di PT. BBM Desa
Piong Kecamatan Sanggar Kabupaten Bima yakni: Pertama kejenuhan karya-wan akan status sebagai karyawan kontrak yang terlalu lama. Kedua perusahaan kurang memperhatikan hal-hal yang dapat diperhitungkan sebagai upah, diantaranya upah tidak masuk kerja karena berhalangan, upah tidak masuk kerja karena melakukan kegiatan lain diluar pekerjaannya, upah karena menjalankan hak waktu istirahat kerjanya. Ketiga hak dan kewajiban masing-masing pihak/ para pihak. Keempat pola pembagian jangka waktu dalam berkerja bagi karyawan kontrak pada ranah sistem bergilir. Hal ini terjadi karena minimnya pengetahuan para karyawan kontrak tentang tata kontrak dan aturan tentang ketenagakerjaan, na mun kesadaran itu mulai timbul berangkat dari permasalahan pemberian jangka waktu yang berbeda dalam berkerja bagi karyawan kontrak sehingga menumbuhkan semangat para karyawan kontrak mencari tahu tentang aturan ketenagakerjaan.

Hal diatas secara langsung memiliki hubungan secara teoritis dengan teori Charles L. Knapp and Nathan M. Crystal bahwa:

Law of contract is atau hukum kontrak adalah mekanisme hukum dalam masyarakat, untuk melindungi harapan-harapan yang timbul dalam pembuatan persetujuan demi perubahan masa datang yang bervariasi kinerja, seperti pengangkutan kekayaan (yang nyata maupun tidak nyata), kinerja pelayanan, dan pembayaran dengan uang [12]

Hal di atas juga sejalan dengan teori Soemitro yang menyatakan bahwa:

Perselisihan atau disebut juga sengketa, konflik dan keresahan merupakan suatu akibat yang terjadi dari hubungan suatu manusia. Yang dimaksud dengan konflik adalah situasi atau keadaan dimana dua atau lebih pihak memperjuangkan tujuan mereka masingmasing yang tidak dapat dipersatukan dan dimana tiap-tiap pihak mencoba meyakinkan pihak lain mengenai kebenaran tujuan masingmasing atau hal yang menimbulkan keresahan [2]. 
4) Pola pembagian jangka waktu dalam berkerja bagi karyawan kontrak pada ranah sistem bergilir

Berdasarkan hasil wawancara yang telah dilakukan pada karyawan, ada dua faktor yang paling meresahkan yakni Pertama pada pola pembagian jangka waktu yang berbeda dalam berkerja bagi karyawan kontrak pada ranah sistem bergilir, Kedua kejenuhan karyawan akan status sebagai karyawan kontrak yang terlalu lama.

Menurut pihak perusahaan hal ini terjadi karena situasi dan kondisi perusahaan/ pekerjaan bukan karena pembedaan perlakuan perusahaan terhadap karyawan kontrak, selain itu dikarenakan ada kemungkinan harus adanya penambahan/ dipanjangkan waktu bagi sekelompok karyawan kontrak lain karena kondisi pekerjaan, misalnya karyawan kontrak sebelumnya diperkerjakan 3 (tiga) bulan lalu tiba giliran bagi sekelompok karyawan kontrak lain, pada tibanya giliran ini memungkinkan kelompok ini akan diperkerjakan selama 4 (empat) bulan karena setelah empat bulan ini dimungkinkan tidak akan ada pekerjaan, hal inilah yang membuat ada pembedaan dalam pembagian jangka waktu berkerja diperusahaan ini dan memang beberapa tahun akhir-akhir sering terjadi hal demikian, semuanya bukan karena ada pembedaan perlakuan. Hal ini bisa dimaklumi akan tetapi wajar karyawan kontrak menuntut hal itu, mengingat hal tersebut sudah terjadi lebih dari satu kali dalam waktu 2 (dua) tahun akhirakhir ini.

Upaya Manajer Perusahaan Mengatasi Keresahan Karyawan Kontrak

Berdasarkan hasil wawancara dari hasil musyawarah untuk mufakat tersebut, upaya pertama yang dijanjikan perusahaan adalah pengangkatan sebagian karyawan kontrak menjadi karyawan tetap. Secara hukum dengan melihat skala perhitungan waktu karyawan berstatus sebagai karyawan kontrak, para karyawan kontrak sudah menjadi karyawan tetap berdasar pada Pasal 54 Undang-undang No. 13 Tahun 2003.
Upayaan pengangkatan sebagian karyawan kontrak menjadi karyawan tetap akan dilakukan pihak perusahaan dengan memperhatikan pribadi para pekerja dan kondisi perusahaan. Upaya pengangkatan ini hanya untuk sebagian karyawan kontrak dan sebagian lainya akan diupayakan menjadi karyawan tetap pada lokasi baru yang perencanaannya akan dibuka.

Upaya selanjutnya yang dilakukan manajer perusahaan adalah mulai memperhatikan hal-hal yang dapat diperhitungkan sebagai upah yang selama ini diabaikan diantaranya adalah upah tidak masuk kerja karena berhalangan, upah tidak masuk kerja karena melakukan kegiatan lain diluar pekerjaanya dan upah karena melaksanakan hak istrahat kerjanya. Untuk menyeimbangkan kebijakan baik untuk karyawan kontrak dan perusahaan, diupayakan dengan segala kebijakan yang diambil oleh manajer perusahaaan berdasarkan hasil musyawarah mufakat dengan para pekerja. Hal ini terlihat secara langsung dari cara pengkalkulasian jumlah hari kerja untuk penghitungan jumlah upah oleh pihak perusahaan, yakni hari dimana karyawan tidak masuk kerja karena berhalangan, melakukan kegiatan lain diluar pekerjaanya dan karena melaksanakan hak istrahat kerjanya mulai dikalkulasikan sebagai jumlah hari kerja para karyawan.

Dari hasil observasi dan wawancara yang dilakukan peneliti bahwa upaya selanjutnya yang dilakukan manajer perusahaan adalah mulai memperhatikan hal-hal yang menjadi hak karyawan yang selama ini kurang diperhatikan diantaranya adalah hak karyawan akan perumusan dan isi perjanjian kerja yang memiliki kekuatan hukum yang sama, hak karyawan akan perumusan peraturan perusahaan dan atas peraturan perusahaan. Dalam menyeimbangkan kebijakan baik untuk karyawan kontrak dan perusahaan, diupayakan dengan segala kebijakan yang diambil oleh manajer perusahaaan berdasarkan hasil musyawarah mufakat dengan para pekerja. 
Perusahaan mulai mengedepankan sikap transparansi dan keterbukaan dalam proses perumusan atau pembahasan ulang isi perjanjian kerja dan peraturan perusahaan, serta mulai memberikan hak para karyawan akan isi perjanjian kerja dan peraturan perusahaan yang memiliki kekuatan hukum yang sama. Hal ini terlihat dari dari langkahlangkah yang diambil pihak perusahaan dengan merumuskan secara berasama dengan karyawan akan perjanjian kerja dan peraturan perusahaan lebih-lebih karyawan mulai sadar akan pentingnya mengikuti proses tersebut.

Dari hasil musyawarah tersebut salah atau kebijakan yang diambil sebagai upaya mengatasi keresahan karyawan kontrak adalah mengoptimalkan pemerataan pola pembagian jangka waktu dalam berkerja dengan sistem bergilir yang diterapkan, dalam skala kebijakan perusahaan mulai diterapkan sistem bergilir dalam berkerja bagi karyawan kontrak dengan jangka waktu yang sama, ujarnya sistem bergilir ini akan tetap diterapkan diperusahaan mengingat kondisi perusahaan/ pekerjaan yang sangat dipengaruhi oleh faktor alam. Selain itu juga perusahaan berupaya mengambil kebijakan yang pada dasarnya berasaskan keadilan. Sistem kerja secara bergilir semata-mata ditetapkan oleh manajer perusahaan agar para pekerja kontrak maupun harian lepas dapat ikut merasakan hasil alamnya walaupun hanya beberapa bulan dalam setahun, namun sewaktu-waktu bisa saja perusahaan sama sekali tidak memperkerjakan karyawan kontrak.

1. Upaya yang dilakukan pihak terkait

a) Pihak Desa

Usaha pihak desa secara langsung dapat meredakan suasana protes dan keresahan karyawan kontrak untuk sementara, jalan kekeluargaan ini ditempuh oleh pihak desa dengan memepertim-bangkan agar karyawan tetap mendapatkan pekerjaan serta keberadaan perusahaan tidak terancam. Menurut pihak desa perusahaan ini adalah perusahaan terbesar diwilayah kecamatan Sanggar yang sejak awal berdirinya banyak memberikan sumbangsih juga berpeng-aruh secara langsung terhadap per-kembangan ekonomi masyarakat sekitar. Dari itu pihak desa berusaha semaksimal mungkin untuk menyelesaikan permasa-lahan tersebut dengan cara dan kebiasaan yang berlaku dimasyarakat (kekeluargaan).

Berdasarkan hasil wawancara yang dilakukan, menurut peneliti usaha pihak desa sudah maksimal dengan berusaha menciptakan kondisi perusahaan dan karyawan kontrak agar tetap harmonis. Terbukti dari upaya pihak desa agar karyawan kontrak tetap mendapatkan pekerjaan serta perusahaan bisa beroperasi sebagaimana biasanya.

b) Pihak Dinas Tenaga Kerja

Keterlibatan pemerintah (cq. Dinas Tenaga Kerja) dalam melakukan fungsi pengawasanya di PT. Bima Budidaya Mutiara (BBM) Desa Piong Kecamatan Sanggar Kabupaten Bima tidak begitu dirasakan oleh karyawan termasuk ketika terjadi perselihan tersebut, kebanyakan karyawan kontrak diawal perselihan tidak tahu harus mengadu kemana akan permasalahan tersebut. Hal ini terjadi karena tidak adanya sikap transparansi perusahaan akan adanya peng-awasan Dinas Tenaga Kerja dan Transmigrasi Kabupaten Bima, pihak pemerintahpun (cq. Dinas Tenaga Kerja) sama sekali tidak pernah mengadakan pertemuan dengan para karyawan baik untuk sosialisasi atau sekedar mencari informasi untuk melaksa-nakan fungsi pengawasan.

Keterlibatan Dinas Tenaga Kerja dan Transmigrasi Kabupaten Bima dalam menjalankan fungsi pengawasan di PT. Bima Budidaya Mutiara (BBM) Desa Piong Kecamatan Sanggar belum optimal mengingat hal-hal yang dialami karyawan. Pihak Dinas Tenaga Kerja dan Transmigrasi Kabupaten hanya melakukan fungsi pengawasan dengan melihat dokumen-dokumen yang ada diperusahaan tanpa melibatkan karyawan secara langsung sebagai bentuk peng-awasan. Sehingga bisa dikatakan pengawasan pihak Dinas Tenaga Kerja dan Transmigrasi Kabupaten Bima terhadap perusahaan tidak berjalan maksimal. Hal ini terjadi murni karena secara kuantitas aparat pengawas perburuhan sangat terbatas jika diban-dingkan 
jumlah perusahaan yang harus diawasi juga karena banyaknya tugas-tugas administratif (jabatan non fungsional) yang dibebankan, sehingga mem-perhambat fungsi pengawasan. Dalam jalanya pemberdayaan karyawan yang terjadi kedatangan pihak Dinas Tenaga Kerja dan Transmigrasi Kabupaten hanya mempelajari, melengkapi dan mengesahkan dokumen yang ada diperusahaan. Harusnya pihak pemerintah secara langsung berinterakasi dengan para karyawan untuk men-getahui kondisi dari segala sisi.

Upaya yang akan dilakukan manajer perusahaan dalam mengatasi keresahan karyawan terhadap perjanjian kontrak kerja di PT. BBM Desa Piong, kebijakan mengenai upaya tersebut tidak secara langsung ditempuh dan diputuskan oleh manajer perusahaan melainkan dihasilkan dari hasil musyawarah untuk mufakat antara manajer perusahaan dengan karyawan kontrak sebagai jalan pertama yang ditempuh. Diantara upaya tersebut adalah mengupayakan pengangkatan pekerja kontrak menjadi pekerja tetap akan tetapi tidak menyeluruh, memperhatikan halhal yang dapat diperhitungkan sebagai upah, penyelenggaraan hak dan kewajiban masingmasing pihak/para pihak secara penuh, dan pemerataan pola pembagian jangka waktu dalam berkerja pada ranah sistem bergilir.

Dari pembahasan diatas dapat disimpulkan bahwa ada hubungan secara teoritis dengan teori di bawah ini:

Penyelesaian secara bipartite yang dimaksudkan disini adalah penyelesaian perselisihan yang dilakukan secara mandiri oleh mereka yang berselisih secara musyawarah mufakat. Penyele-saian secara bipartite ini diperlukan dalam kerangka pengejawatahan sila keempat dari Pancasila yang sudah merupakan pandangan hidup dari bangsa yang sejak dahulu kala. Musyawarah mufakat yang demokratis dapat menyelesaikan permasalahan sehingga terhindar dari proses yang berkepanjangan [3] .

Maksud dari penyelesaian ini adalah terhadap manajer perusahaan dalam mengatasi keresahan karyawan terhadap perjanjian kontrak kerja di PT. BBM Desa Piong, hubungan tersebut terlihat dari upaya yang dilakukan manajer perusahaan untuk mengatasi perselisihan dengan jalan musyawarah untuk mufakat dengan karyawan kontrak. Dari hasil musyawarah mufakat tersebut dihasilkan beberapa upaya yang dilakukan manajer perusahaan dianta-ranya mengupayakan pengangkatan pekerja kontrak menjadi pekerja tetap akan tetapi tidak menyeluruh, memperhatikan hal-hal yang dapat diperhitungkan sebagai upah, penyelenggaraan hak dan kewajiban masingmasing pihak/para pihak secara penuh, dan pemerataan pola pembagian jangka waktu dalam berkerja bagi karyawan kontrak pada ranah sistem bergilir.

\section{Simpulan}

Hubungan hukum perjanjian kontrak kerja antara karyawan dengan manajer PT. BBM Desa Piong berdasarkan Undang-undang No. 13 Tahun 2003 tentang Ketenagakerjaan setelah adanya KKWT pertama dan selanjutnya. Disepakati beberapa hal oleh para pihak yakni srtuktur upah, penyelenggaraan hak dan kewajiban para pihak, penerapan sistem bergilir dalam berkerja bagi karyawan kontrak dan mengenai status. Dari segi pelaksanaanya ada beberapa pelanggaran yang dilakukan oleh perusahaan diantaranya adalah status para karyawan sebagai karyawan kontrak melebihi batas minimum kontrak, halhal yang dapat diperhitungkan sebagai upah, perumusan perjanjian kerja tidak dilibatkan karyawan secara langsung serta isi KKWT yang memiliki kekuatan hukum yang sama tidak diberikan pada karyawan, peraturan perusahaan yang disahkan oleh pemerintah yang berwajib tidak diberikan pada karyawan dan terakhir pemberian jangka waktu yang berbeda dalam sistem bergilir bagi sebagian karyawan kontrak.

Faktor penyebab timbulnya keresahan karyawan terhadap perjanjian kontrak kerja di PT. BBM Desa Piong Kecamatan Sanggar Kabupaten Bima yakni: Pertama kejenuhan karyawan akan status sebagai pekerja kontrak 
yang terlalu lama. Kedua perusahaan kurang memperhatikan hal-hal yang dapat diperhitungkan sebagai upah, diantara-nya upah tidak masuk kerja karena berhalangan, upah tidak masuk kerja karena melakukan kegiatan lain diluar pekerjaannya, upah karena menjalankan hak waktu istirahat kerjanya. Ketiga hak dan kewajiban masing-masing pihak/para pihak. Keempat pola pembagian jangka waktu dalam berkerja bagi karyawan kontrak pada ranah sistem bergilir.

Upaya yang dilakukan manajer perusahaan dalam mengatasi keresahan karyawan terhadap perjanjian kontrak kerja di PT. BBM Desa Piong, adalah: Pertama mengupayakan pengangkatan pekerja kontrak menjadi pekerja tetap akan tetapi tidak menyeluruh. Kedua memperhatikan hal-hal yang dapat diperhitungkan sebagai upah. Ketiga penyelenggaraan hak dan kewajiban masing-masing pihak/para pihak secara penuh. Keempat pe-merataan pola pembagian jangka waktu dalam berkerja bagi karyawan kontrak pada ranah sistem bergilir.

\section{Referensi}

[1] D. T. K. R. Indonesia, Undang-Undang RI no. 13 tahun 2003 Tentang Ketenagakerjaan. Cipta Jaya, 2003.
[2] L. Husni, Pengantar Hukum Ketenagakerjaan Indonesia. Rajawali Pers, 2010.

[3] Z. Asyhadie, "Hukum Kerja: Hukum Ketenagakerjaan Bidang Hubungan Kerja,” Jakarta Raja Graf. Persada, 2007.

[4] D. Sukandar, Membuat Surat Perjanjian. Yogyakarta: CV. Andi Offset., 2011.

[5] A. Novius, "Perusahaan di Indonesia (Phenomenon Employee/ Laborer 's Benefit in Indonesian Corporates )," 2007.

[6] Sugiyono, "Metode Penelitian kuantitatif kualitatif dan R dan D," Alf. Bandung, 2010.

[7] L. J. Moleong, Metode Penelitian Kualitatif. Bandung: Remaja Rosdakarya, 2007.

[8] B. A. S. Afifuddin and B. A. Saebani, "Metodologi penelitian kualitatif," Bandung CV Pustaka Setia, 2009.

[9] S. Hadi, "Metodologi research jilid I," Yogyakarta Andi, vol. 94, p. 95, 2004.

[10] M. B. Miles and A. M. Huberman, Analisis Data Kualitatif. Terjemahan Tjetjep Rohendi Rohidi. 1992.

[11] B. S. Sastrohadiwiryo, Manajemen tenaga kerja indonesia: pendekatan administratif dan operasional. Bumi aksara, 2002.

[12] H. S . Salim, Hukum kontrak: Teori dan teknik penyusunan kontrak. Sinar Grafika, 2003. 